\title{
Financièrement indépendant après un accident?
}

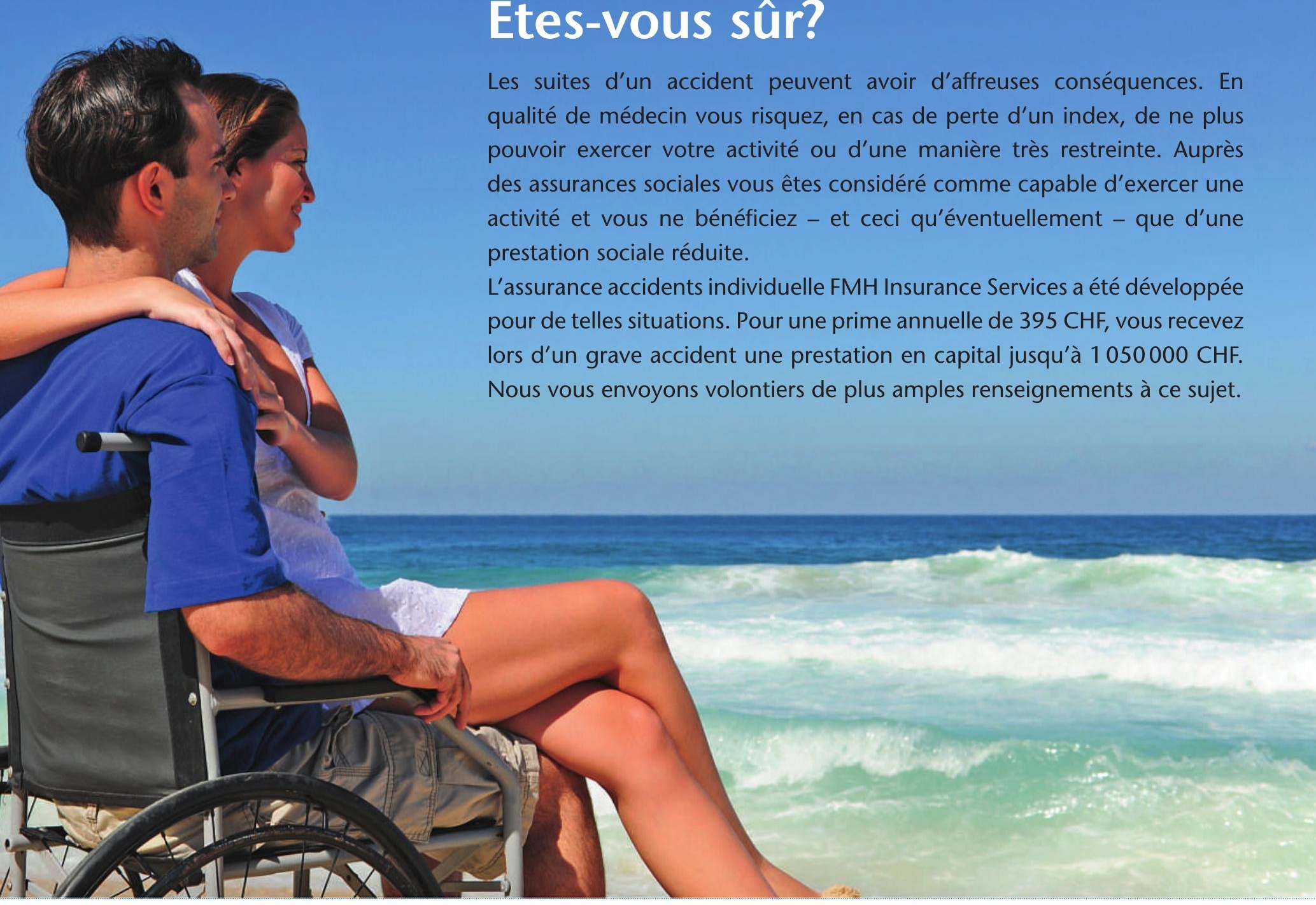

$\square$ Je veux être financièrement indépendant. Envoyez-moi des informations sur l'assurance accidents individuelle.

$\square$ Je désire être conseillé. Téléphonez-moi.

$\square$ Je suis intéressé par un conseil global sur la prévoyance et/ou une planification financière.

\section{Prénom/Nom}

Adresse

NPA/Lieu

Date de naissance

Téléphone privé/cabinet

Atteignable le plus facilement

Adresse e-mail

\section{Etes-vous sûr?}

Les suites d'un accident peuvent avoir d'affreuses conséquences. En activité et vous ne bénéficiez - et ceci qu'éventuellement - que d'une prestation sociale réduite.

L'assurance accidents individuelle FMH Insurance Services a été développée $000 \mathrm{CHF}$ Nous vous envoyons volontiers de plus amples renseignements à ce sujet. 